\title{
South African Film Industry
}

\author{
By Martin P. Botha \\ Spring 1995 Issue of KINEMA
}

\section{THE SOUTH AFRICAN FILM INDUSTRY: FRAGMENTATION, IDENTITY CRISIS AND UNIFICATION}

\section{Introduction}

Film and video are regarded as vital in South Africa's transition. Amongst others, film and video can foster a stable, democratic and united society. However, the South African film industry cannot fulfil this role at present due to fragmentation and consequently an identity crisis. The industry therefore needs to change. One of the key players in previous debates about the restructuring of the local industry, the Film and Allied Workers' (FAWO) Distribution Committee chairman, Seipati Bulane-Hopa, describes the need for cinema in our society in these words:

Cinema ... serves as a vehicle for people to articulate their different social affiliations and define their respective historic cultures, traditions, social and political experiences. If cinema is only used to entertain and not to educate, then the chances of transforming our society are slim (Blignaut \& Botha, 1992, p.88).

And in the words of Lawrence Dworkin, the necessity of a local cinema is described as follows:

As we move towards a democratic dispensation we must ensure that our cinema is able to cross over all historically created divisions as a profound, entertaining and liberating medium of mass communication (Blignaut \& Botha, 1992, p.90).

One can argue that film is an important part of the cultural domain in any country, but particularly so in South Africa where social change depends on the quality of communication in the society. Communication is one of the cornerstones of democracy, and film and video can make an important contribution to the democratisation and development that need to take place within this society. Film and video can be effectively used in intensive educative and informative campaigns in respect of political tolerance and the workings of democracy, as well as health issues. In a population with high illiteracy levels, films and videos can be circulated through cinemas and television, and especially through a network of mobile video vans in rural areas that have no access to television or cinemas. Mobile video vans were, for example, successfully used during the Namibian transition. In addition, as forms of popular fiction, films and videos such as Taxi to Soweto can explore the changes taking place in South Africa in a way that helps people to make sense of these dramatic changes.

At present, it is sad to say, South Africa has a deeply fragmented film industry and virtually no national film identity. The reason for this fragmentation and lack of identity is multifaceted, each facet interacting to produce a complicated set of associations and relationships. Various academic scholars such as Pieter Fourie of Unisa (Fourie 1981), Keyan Tomaselli (Tomaselli 1989) and John van Zyl (Van Zyl 1985), as well as research teams within the industry, such as FAWO's Film Commission spent time in identifying and analysing the ills of our industry. Two books were published during the 1990s on the local industry which also addressed the reasons for its collapse (see Botha \& Van Aswegen, 1992; Blignaut \& Botha, 1992; see also Botha, Blignaut \& Swanepoel, 1992).

\section{Reasons for the fragmentation and lack of identity}

In a nutshell, one could say that the apartheid policy as well as state-subsidised film structures have contributed to the severe fragmentation of our industry (Nathan 1991; Tomaselli 1989). Since 1956 and the introduction of a regulated subsidy system, government and big business have collaborated to manipulate cinema in South Africa. Ideology and capital came together to create a national cinema that would reflect South Africa during the Verwoerdian regime. However, it was initially a cinema for whites only, and predominantly Afrikaans. Of the 60 films made between 1956 and 1962, 43 were in Afrikaans. Four were bilingual and the remaining 13 were English. The subsidy system rewarded box-office success. Once a film had earned 
a specific amount of money at the box-office, it qualified for the subsidy which paid back a percentage of costs. This percentage was initially higher for Afrikaans films than for English productions. It is therefore evident that the government of the day realised the potential influence this Afrikaner-dominated industry would have on the growth and spread of the Afrikaans language. Since 1962, Afrikaner capital became a significant factor in the industry when the insurance company SANLAM acquired a major interest in Ster-films, a distribution company with the explicit intention to provide cinema predominantly for Afrikaner patrons. By 1969, Satbel (the Suid-Afrikaanse Teaterbelange Beperk) was formed, and the financing, production and distribution of films in South Africa were now virtually in the hands of one large company (except for a few cinemas owned by CIC-Warner). The white Afrikaans audience for the local cinema was relatively large and very stable, guaranteeing nearly every Afrikaans film a long enough run to break even as long as it provided light entertainment and dealt with Afrikaner reality and beliefs (Davies 1989).

With a few exceptions ${ }^{(1)}$, the films were unremarkable. Fourie (1981) attributes this to the conservative attitude of Afrikaners at that stage towards the films. Afrikaners wanted their ideals visualised in these films. This idealistic conservatism was characterised by an attachment to the past, to ideals of linguistic and racial purity and to religious and moral norms. The films had to subscribe to these conservative norms in order to be successful at the box-office. The films seldom attempted to explore a national cultural psyche. As such, they were a closed form, made by Afrikaners for Afrikaners, with little or no attention to their potential to say something important about their society to an international audience. The type of realism that could have analysed Afrikaner culture in a critical manner was avoided. Instead use was made of folk stereotypes that showed the Afrikaner as chatty, heart-warming and lovable in a comedy tradition, or as beset by emotional problems that had little to do with society, but much to do with the mainsprings of western melodrama about mismatched couples overcoming obstacles on the path to true love (see especially Pretorius, in Blignaut \& Botha 1992). These films ignored the socio-political turmoil, as well as the realities experienced by black South Africans.

Fourie (1982) argued that most Afrikaans films communicated by means of obsolete symbols that had little intercultural communication value. They painted a one-sided and stereotypical portrait of the Afrikaner, leading to a misconception about who and what the Afrikaner was. Furthermore, the negative portrayal of blacks as a servant class in these films is a visual symbol of the deep-seated apartheid ideology.

The Afrikaans film, with a few exceptions ${ }^{(2)}$ including television dramas and series, stagnated during the past three decades and even disappeared in the 1980s. In the 1990s, the Afrikaans film will have to adapt to the drastic changes in South African society, or else become totally irrelevant when their themes are measured against the viewers' own experience (Pretorius, in Blignaut \& Botha 1992).

Another contributor to the fragmentation of the national film industry was the creation of a so-called "Bantu" film industry during the 1970s. This boost to "black" films resulted in the making of a large number of shoddy films in ethnic languages that were screened in churches, schools and community and beer halls. It was contrary to government policy to allow black cinemas in the urban "white" areas, as this would concede the citizenship of urban blacks. The urbanisation of blacks was portrayed as uniformly negative and homeland life as more fitting (Gavshon 1983; Van Zyl 1985). At this stage, black and white audiences were treated differently. The audiences were separated, each with its own set of rules and operations, films and theatres. Any film that managed to be made which in any way reflected the South African society in turmoil, was banned by the state, or received no distribution whatsoever, and thus did not qualify for any film subsidy. A true national film industry did not therefore develop through the Bantu film industry -- only a few inferior paternalistic films for blacks were made, chiefly by whites.

During the mid-1980s the industry was further fragmented. By means of substantial tax concessions that made investing in film an attractive option, a boom occurred in the commercial industry (see Accone 1990a; 1990b; Powell 1990; Schoombie 1990; Silber 1990a, 1990b; Blignaut \& Botha 1992). Several hundreds of films were made, mostly inferior imitations of American genre films (see for example Blignaut \& Botha, 1992). The majority of these tax shelter films did not reflect any recognisable socio-political reality or national culture. At the end of the 1980s, the tax shelter scheme collapsed and the current subsidy system again only pays subsidy on box-office returns.

The history of film distribution in South Africa has sadly been one of racism and segregation (see for example 
Tomaselli 1989). Only in 1985 did the distributors manage to desegregate some cinemas, and for the first time the existence and importance of the majority of South Africans, deprived both socially and economically of the chance to be part of a cinema-going public, were acknowledged.

Ster-Kinekor and Nu Metro, as well as UIP, control the distribution of films in South Africa. In contrast to these three giants, independent cinemas are largely second-run cinemas (screening films that have already played the major networks), playing double-bill shows, at minimal ticket fares. There were approximately 202 independent cinemas in South Africa during $1992^{(3)}$ and some were in the process of closing down (see Blignaut 1990). The independent cinema of the 1980s which was critical of apartheid and which received international acclaim, was chiefly distributed through the independent venues. The independent theatres however don't qualify for state subsidy regarding box-office income. The film makers of films critical of apartheid seldom see their work being distributed by the main distribution companies. In fact, American imports dominate the mainstream networks. Films such as Jobman, Mapantsula, Windprints, On the Wire and several other examples of the independent film revival of the 1980s were seldom seen by the majority of South Africans. This part of the local film industry has been forced to become something of an export industry although it dealt with the realities of blacks in this country (see Bauer 1987; Botha 1990; Botha \& Burger 1989; Botha \& Van Aswegen 1992).

The film movement of the 1980s and unification within the industry during the 1990s

Since the late 1970s and the early 1980s a group of film and video producers who were not affiliated to the established film companies in the mainstream industry, made films about the realities of the majority of South Africans. ${ }^{(4)}$ Most of the films were shown at film festivals, universities, church halls, trade union offices and the private homes of interested parties. Most of the films experienced censorship problems during the State of Emergency. The films had small budgets and were either financed by the producers themselves, by progressive organisations or with the assistance of the tax benefit system of the 1980s (Tomaselli, 1989). The films were chiefly the product of two groups that emerged jointly: a group of white university students opposed to apartheid, and black workers who yearned for a film form using indigenous imagery that would portray their reality in South Africa, that would give them a voice and space in local films.

This remarkable process of intercultural communication led to a mass movement of workers, students and members of youth, sport and church organisations who united in their opposition to apartheid. The production of audio-visual material, forms of communication that required specialised production skills and money not necessarily found in the black worker class, was a further indication of the process of intercultural communication that was taking place. This process contributed to the formation of FAWO in September 1988. One of the aims of FAWO is to unite all film makers within South Africa to establish a democratic society (Currie 1989; Metz 1990). Together with numerous documentaries, community videos and the rise of short fiction and animation film making, full-length films such as Mapantsula marked the beginning of a new, critical South African cinema. Botha and Van Aswegen (1992) referred to this cinema as the alternative film movement of the 1980s. It is evident that this new cinema is based on audio-visual material that reflects the realities of the black majority. It constitutes a valid part of our national film industry (see Botha \& Van Aswegen, 1992). It is from these films that the symbols and iconography of a national film industry can be drawn, rather than from the diversions produced by the Afrikaans cinema, the "Bantu" film industry and the tax shelter films.

Approximately 944 features were made in South Africa in the period 1979 to 1991, as well as nearly 998 documentaries and several hundred short films and videos (see Blignaut \& Botha 1992). Although most of the features were of mediocre value, at least 20 to 30 remarkable indigenous local feature films were made. They included Mapantsula (which participated in the Un Certain Regard section at Cannes), Marigolds in August (a winner of two Silver Bears at Berlin), On the Wire, the brilliant The Road to Mecca (which was highly applauded at film festivals in India and Canada), the interracial drama Saturday Night at the Palace, the Mannheim Jury Prize Winner Shotdown, the evocative Afrikaans dramas Fiela se Kind and Die Storie van Klara Viljee, Manie van Rensburg's four-hour director's cut of The Fourth Reich about Afrikaner nationalism, and the Darrell Roodt trilogy (Place of Weeping, The Stick and Jobman). Since 1991, coproductions have led to two local films receiving international attention: Darrell Roodt's Sarafina! and Elaine Proctor's Friends. 


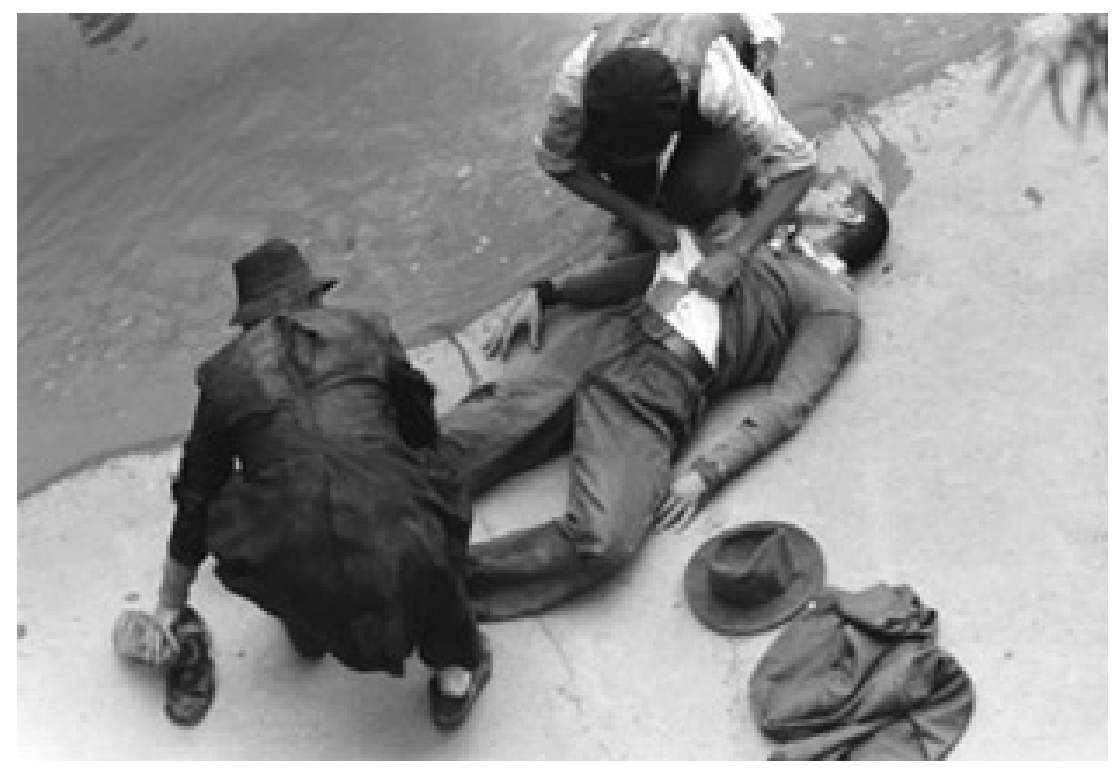

Figure 1: Jobman (dir. Darrell Roodt, 1990)

Although apartheid was officially still in place during the making of films such as Mapantsula, Jobman, On the Wire and The Stick, these features, together with numerous community and resistance videos became vital instruments in the anti-apartheid struggle. Three major elements of these features were that (a) they were produced by means of co-productions with or solidarity assistance from progressive non-South Africans; (b) South Africans were significantly involved in most if not all spheres of production as opposed to Hollywood films on apartheid; and (c) the exhibition and distribution of these films, especially the community videos and documentaries on the evils of apartheid were one great problem area. Mapantsula and The Stick, for example, were only unbanned after 1990, and Jobman has still not been commercially released in our country. Most of these films were screened at alternative venues like community halls, churches in the townships, selected progressive film festivals and even at private homes.

As mentioned previously, it is from these films that the symbols and iconography of a national South African film industry can be drawn, although many questions regarding a national cinema ought to be addressed in future debates. These films can be described as progressive film texts in the sense that all of them are consciously critical of apartheid, either in a historic (Fiela se Kind, Jobman) or a more contemporary (the South Africa of the 1980s in Mapantsula) context. They deal with the lives and struggle of the people in a developing country and are mostly allied with the liberation movements for a non-racial South Africa.

Mapantsula is an example of recent local filmmaking that represents a voice of resistance which echoes in the popular culture and memory of the majority of South Africans. The existence and experience of township life was severely censored and withheld from the media before 1990. The workings of the Publication Control Act, coupled with the State of Emergency and the regulations accompanying it, were just two of the more obvious means to achieve this media "silence." Features such as Mapantsula, Jobman and On the Wire were a critical and necessary intervention in the representation of this usually hidden reality on South African screens. These films, like the recent Come See the Bioscope, try to recover popular memory. They deal with events which were conveniently left out in official South African history books or in a contemporary context in actuality programmes on national television. Therefore, they became guardians of popular memory within the socio-political process in our country.

The films examine the South African reality critically. Existing myths and stereotypes associated with apartheid have been questioned, examined and their falseness revealed. South African reality is observed mainly from the viewpoint of black South Africans. For too long many whites in this country have ignored the values and norms of our fellow South Africans. In this respect the new critical cinema is meaningful for intercultural communication and intercultural relations: on the one hand it offers to South Africans who 
are opposed to apartheid a voice and space; on the other hand, many whites, who are considered part of the status quo of apartheid, are given the opportunity of familiarising themselves with people who belong to other cultures and ideological groups and who have, due to racial segregation, different spheres of life.

Another positive development during the early 1990s was the perception from all sectors of the industry that cinema has a vital role to play in the forging of social cohesion and the process of democratisation and development that so urgently needs to take place. In 1991 the Film and Broadcasting Forum (FBF) was established to address the problems of the industry. It was widely considered to be an important step in the consultation process that resulted during 1993 in the creation of a single body, motivated by mutual interests. In composition, the FBF represented the widest possible cross section of industry interests, from producers through to directors, writers, actors, musicians, technicians, agents, managements and studios. It also included both progressive and more establishment-oriented groupings, some of whom have hitherto not been overly co-operative. The FBF described its prime objective as the creation of an environment in which its members could address strategic issues of common interest and to discuss such strategies with the state, political parties, cultural groups, broadcasters, distributors, exhibitors and others. A main aim was the establishment and development of a representative and indigenous South African film culture which would redress the political imbalance of the past to ensure equal access for all South Africans to film structures. From this consultative process, an interim consensus document emerged which tried to address the restructuring of the local film industry.

This resulted during 1993 in the creation of the Film and Broadcasting Steering Committee, representing the eight major film organisations in local cinema. The Film and Broadcasting Steering Committee has been painstakingly working on proposals for a South African Film Foundation for more than a year. The proposed structures will be modelled on the French film structures in France and Burkina Faso. By mid-1994 the Film and Television Federation emerged from the Broadcasting and Film Steering Committee.

Another fascinating development is the rise in local short film production which is presented to the public every year at the annual Weekly Mail/Guardian Weekly film festival's Short Film Competition. In the past films such as Sales Talk and the animation work by William Kentridge; Sacrifice, about the disintegration of an Afrikaner family and Guy Spiller's The Boxer, about white working class fears regarding political change in South Africa, stunned audiences. Last year 37 short films were screened at the festival. Catherine Meyburgh's The Clay Ox, about white South Africans trying to redefine their role in an apartheid society and to come to terms with their heritage, gave one new hope for another revival in innovative local filmmaking. A South African Film Foundation has been established by members of the Weekly Mail Film Festival, COSAW, the National Arts Initiative and others in order to stimulate the independent film sector, but this body should not be confused with the proposed statutory body.

The local pay-television network M-Net has provided funding for the making of 30-minute films in their project New Directions: The Rhythm of our lives. Kenneth Kaplan's The Children and I, Rozelle Vogelman's The Apology, Lance Gewer and Zaharia Rapola's Come See the Bioscope and Peni Flascas's Learning the Hard Way were broadcast on the network in February 1994. The project is an important showcase of new, young talent in this country and especially The Apology about pupils' reactions to an abortion case at school, and the evocative Come See the Bioscope about ANC member Sol Plaatje's attempts to educate rural blacks politically, stood out.

Film distribution remains a big problem in South Africa. The majority of South Africans are not reached by means of Ster-Kinekor and Nu Metro's distribution networks. FAWO and the Film Resource Unit have therefore embarked on the Video Suitcase Project which entails video distribution by means of mobile units. Videos of African and Latin American directors such as Ousmane Sembene, Souleymane Cissé and Fernando Solanas, as well as local films are distributed to new audiences in townships and rural areas. Slowly but surely a national film culture is emerging in South Africa. The training especially of black filmmakers at the Newtown Film and Television School in Johannesburg will give further impetus to this emerging film culture.

The new democratic government has also announced programmes for training black film makers. Furthermore, the rural university of Fort Hare has been proposed as a venue for a film school, and the African Film and Television Collective and the Black Film Foundation were established to assist black film makers. 
Co-operation with the Pan African Federation of Filmmakers seems to be a future possibility, turning South Africa into a potential new market for African cinema.

Although feature film production has dropped from 170 features per year in 1988 to less than 10 last year, the proposals by the Film and Broadcasting Steering Committee for new film structures and funding schemes in a democratic South Africa will eventually result in a true national, indigenous cinema.

The developments in the new South African cinema of the 1980s as well as recent proposals within the industry for new structures are definite indicators that a democratic, indigenous South African aesthetic reflecting positive cultural elements is within the capacity of South African directors. As Keyan Tomaselli (1990:4) states:

For the first time in our history, the social, economic and political conditions which sparked progressive film movements in other countries, are present in South Africa. We need to seize this moment and pilot the film industry as a whole to its full potential as an accelerator, rather than as a brake, to the future which has deluded us for so long.

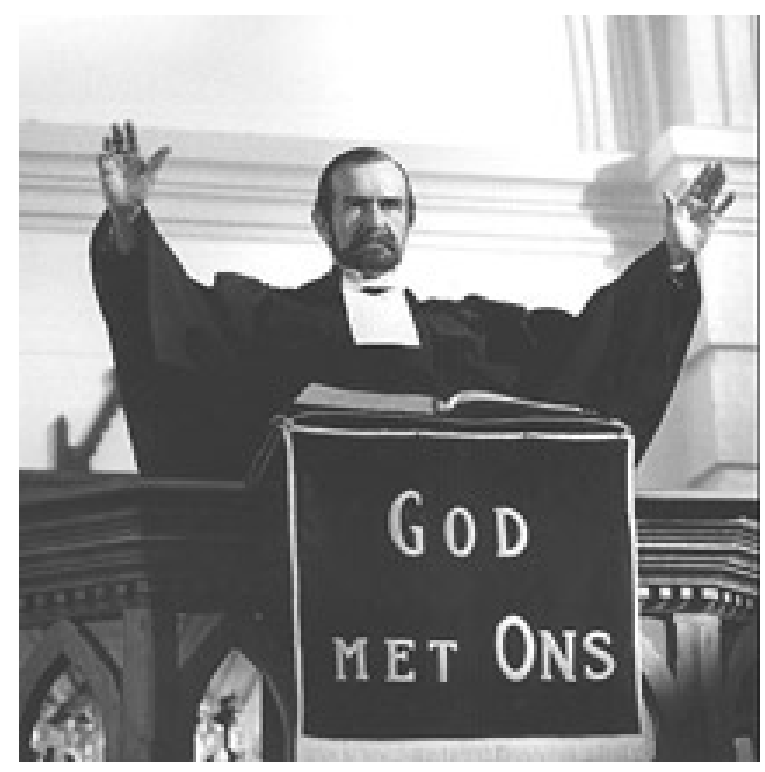

Figure 2: Road to Mecca (dir. Athol Fugard and Peter Goldsmid, 1992)

\section{Notes}

1.The films by Jans Rautenbach and Emil Nofal, namely Die Kandidaat, Katrina and Jannie Totsiens, were successful alternatives to the numerous Afrikaans escapism fare of the 1960s and early 1970s. After the introduction of television in 1976, some Afrikaans film makers such as Manie van Rensburg made brilliant dramas and series for local television. In fact, Van Rensburg became a chronicler of the Afrikaner psyche in revisionist dramas such as Verspeelde Lente and Die Perdesmous, which led to his international reputation with films like The Fourth Reich.

2. Films such as Rautenbach's Broer Matie, Johan Blignaut's Mamza and Tojan, Katinka Heyns's Fiela se Kind and Frans Nel's 'n Wêreld sonder Grense were notable exceptions to the mediocre fare in Afrikaans cinema during the 1980s.

3. Statistics on the number of independent theatres were provided by Johan Blignaut of Showdata on 28 October 1994.

4. Publications by Blignaut and Botha (1992), Botha and Van Aswegen (1992) and Tomaselli (1989), as well as festival brochures by the Weekly Mail Film Festival have dealt in some detail with these film makers and 
their films.

\section{References}

ACCONE, D. Salvation of SA film in "better Govt funding." The Star Tonight!, 19 Jan. 1990a: 1-2.

ACCONE, D. Some see new film subsidy as disaster. The Star Tonight!, 1 March 1990b: 1.

BAUER, C. Breaking the local no-sound barrier. Weekly Mail, 2 April 1987: 21.

BLIGNAUT, J. 1990. The distribution dilemma of local product. In: BLIGNAUT, J. \& METZ, C. (eds.) Showdata Bulletin Vol. 2. Johannesburg: Showdata, 2-3.

BLIGNAUT, J. \& BOTHA, M.P. (eds.) 1992. Movies Moguls Mavericks: South African Cinema 1979-1991. Auckland Park, Johannesburg: Showdata.

BOTHA, M.P. Probleme om oplewing in S.A. film. Die Volksblad, 4 Jan. 1990: 6.

BOTHA, M.P., BLIGNAUT, J. \& SWANEPOEL, J. 1992. The problems of the mainstream film industry in South Africa. Paper read at a conference on "De Weerspiegeling van de Zuidafrikaanse socio-politieke realiteit in de onafhankelijke film" in Brussels, Belgium, from 4-8 May 1992.

BOTHA, M.P. \& BURGER, F. A weathervane in uncertain winds. Weekly Mail, 14 - 20 Jul. 1989: 21, 24.

BOTHA, M.P. \& VAN ASWEGEN, A. 1992. Images of South Africa: The rise of the alternative film. Pretoria: Human Sciences Research Council.

CURRIE, W. 1989. Film and video workers organise. South African Labour Bulletin, 14(5): 7-12.

DAVIES, J. 1989. S.A. Film: A brief history. ADA, 6:32-33.

FOURIE, P.J. 1981. 'n Struktureel-funksionele model vir die formulering van 'n Suid- Afrikaanse rolprentbeleid. Pretoria: UNISA. (Ongepubliseerde doktorale tesis).

FOURIE, P.J. 1982. Interkulturele probleme in beeldkommunikasie. Communicare, 3(1): 60-73.

GAVSHON, H. 1983. Levels of intervention in films made for African audiences in South Africa. Critical Arts 2(4): 13-21.

METZ, C. 1990. FAWO. In: BLIGNAUT, J. \& METZ, C. (eds.) Showdata Bulletin, Vol. 7. Johannesburg: Showdata, 1,4 .

NATHAN, J. 1991. Movies and monopolies: The distribution of cinema in South Africa. Staffrider 9(4): 61-84.

POWELL, I. A snip off the old film subsidy scheme. Weekly Mail, 2 - 8 March 1990: 21-22.

PRETORIUS, W. 1992. Afrikaans cinema. In: BLIGNAUT, J. \& BOTHA, M.P. (eds.) Movies Moguls Mavericks: South African cinema 1979-1991. JHB, Showdata, 375-394.

SCHOOMBIE, S. "Die pasiënt is doodsiek." Kalender, bylae tot Beeld, 12 Februarie 1990: 2.

SILBER, G. Tax, lies and videotape. The Executive, June 1990a: 68-74.

SILBER, G. 1990b. Who killed the South African film industry? In: BLIGNAUT, J. \& METZ, C. (eds.) Showdata Bulletin, Vol. 4. Johannesburg: Showdata, 2-4.

TOMASELLI, K.G. 1989. The cinema of Apartheid: Race and class in South African film. Sandton: Radix.

TOMASELLI, K.G. 1990. Cultural reconstruction in South African Cinema. In: BLIGNAUT, J. \& METZ, C. (eds.) Showdata Bulletin, Vol. 5 Johannesburg: Showdata, 2-4.

VAN ZYL, J. 1985. A reeling industry: Film in South Africa, Leadership S.A. 4(4): 102-106. 


\section{Author Information}

Martin P. BOTHA is Associate Professor of Film and Media Studies at the University of Cape Town. He has published more than 200 articles, reports and papers on South African media, including six books on South African cinema. His most recent book is South African Cinema 1896-2010 (Bristol: Intellect, 2012). 